\title{
Peningkatan Profesionalitas Guru Dalam Pemanfaatan Lingkungan Sekolah Sebagai Sumber Belajar Melalui In House Training
}

\author{
Marjono Memet ${ }^{1 *}$ iD \\ ${ }^{1}$ SMA Negeri 2 Leuwidarman, Banten, Indonesia \\ *Corresponding author: marjonomemet56@gmail.com
}

\begin{abstract}
Abstrak
Penelitian ini dilaksanakan bertujuan untuk mendeskripsikan Profesionalisme guru dalam memanfaatkan lingkungan sekolah sebagai sumber belajar. Bagaimana kecermatan guru dalam melihat potensi lingkungan sebagai sumber Belajar, hal inilah yang menjadi konsentrasi peneliti. Penelitian ini dirancang dalam bentuk Penelitian Tindakan Sekolah yang direncanakan dilaksanakan dalam dua siklus, dimana setiap siklus nya dilaksanakan dalam dua kali pertemuan. Adapun subjek penelitian ini adalah guru-guru yang terdiri dari dua guru Bahasa Indonesia dan tiga orang guru IPA, dua orang Guru Matematika, satu guru PAI dan dua orang guru Bahasa Inggris. Pelaksanaan penelitian ini diawali dengan pengumpulan data dan menggunakan format observasi, instrumen penilaian skenario pembelajaran dan instrumen penilaian pelaksanaan pembelajaran. Selanjutnya data yang sudah terkumpul dianalisis dengan menggunakan analisis deskriptif yang hasilnya adalah: hasil siklus I nilai rata-rata yang diperoleh adalah 86 dan hasil siklus II nilai rata-rata yang diperoleh adalah 93 . Berdasarkan uraian tersebut dapat disimpulkan bahwa hasil yang dicapai dari siklus I ke siklus II, terjadi peningkatan pada nilai rata-rata yang diperoleh dari masing-masing komponen yang di observasi maupun yang dinilai, ini berarti bahwa pembinaan dan bimbingan melalui pendekatan In House Training dapat meningkatkan profesionalitas guru dalam pemanfaatan lingkungan sekolah sebagai sumber belajar.
\end{abstract}

Keywords: Profesionalitas Guru, Lingkungan Sekolah, In House Training

\section{Abstract}

This research was conducted to describe the teachers' professionality in utilizing the school environment as a learning sources. How careful the teacher is in seeing the potential of the environment as a source of learning, this is the concern of researchers. This research is designed in the form of School Action Research which is planned to be carried out in two cycles, where each cycle is carried out in two meetings. The subjects of this study were teachers consisting of two Indonesian language and three science teachers, two Mathematics teachers, one Islamic Education teacher and two English teachers. The implementation of this research begins with data collection and uses the observation format, learning scenario assessment instruments and learning implementation assessment instruments. Furthermore, the data that has been collected is analyzed using descriptive analysis, which resulted: the cycle I result has the average value obtained 86 and in cycle II, the average value obtained is 93. Based on these descriptions, it can be concluded that the results achieved from cycle I to cycle II increase in the average value obtained from each component that was observed and assessed. This means that coaching and guidance through the In House Training approach can improve teachers' professionality in using the school environment as a learning sources.

Keywords: Teacher Professionalism, School Environment, In House Training

$\begin{array}{lll}\text { History: } & \text { Publisher: Undiksha Press } \\ \text { Received : } 20 \text { Mei } 2020 & \text { Licensed: This work is licensed under } \\ \text { Revised } \quad \text { 1 Juni } 2020 & \text { a Creative Commons Attribution 3.0 License } \\ \text { Accepted : 6 Juli } 2020 & \\ \text { Published : } 30 \text { Juli } 2020 & \end{array}$




\section{Introduction}

Keberadaan lingkungan dalam proses pembelajaran menjadi salah satu factor keberhasilan proses pembelajaran, dimana dengan adanya lingkungan proses pembelajaran akan lebih menarik, belajar lebih bermakna, bahan pembelajaran lebih faktual, kegiatan belajar lebih konprehensif, sumber belajar lebih kaya, serta membentuk pribadi siswa agar tidak asing dengan kehidupan sekitar. Hal ini didukung oleh pendapat Rohayati, (2018); Rochanah, (2018) yang menyatakan bahwa memanfaatkan lingkungan sebagai media pembelajaran akan menjadikan proses belajar mengajar lebih bermakna, karena para siswa dihadapkan langsung pada peristiwa dan keadaan yang sebenarnya secara alami. Jadi, dengan adanya lingkungan proses pembelajaran akan lebih bermakna terhadap perkembangan pengetahuan siswa.

Namun kenyataan yang terjadi, masih ada guru yang mengabaikan pemanfaatan lingkungan sebagai sumber belajar. Berdasarkan pengamatan selama pelaksanaan supervisi sekolah banyak sumber belajar yang bisa dimanfaatkan oleh guru dalam melaksanakan pembelajaran. Ada beberapa jenis lingkungan sekolah yang dapat dijadikan sebagai sumber belajar seperti: tempat ibadah, taman sekolah, koperasi sekolah, perpustakaan sekolah, organisasi siswa (OSIS), dan sebagainya. Akan tetapi guru hanya memilih membelajarkan siswa di kelas dan guru berpedoman hanya kepada buku yang satu-satunya dijadikan sebagai sumber belajar di sekolah. Kondisi ini didukung oleh hasil observasi dan hasil wawancara.

Seperti observasi awal yang dilakukan Peneliti di SMA Negeri 2 Leuwidamar, terhadap guru-guru yakni (guru bahasa Indonesia, guru IPA, Biologi, Matematika, guru Agama dan guru Bahasa Inggris) di sekolah tersebut cenderung pemanfaatan lingkungan sekolah sebagai sumber belajar hanya kadang-kadang saja hanya 4-5 kali. Guru lebih sering menyajikan pelajaran di dalam kelas walaupun materi yang disajikan berkaitan dengan lingkungan sekolah. Dari wawancara yang dilakukan, sebagian besar guru menyatakan belum memanfaatkan lingkungan sebagai sumber belajar secara maksimal, karena beberapa alasan, alasan tersebut antara lain, siswa sulit diawasi jika dilaksanakan pembelajaran di luar kelas, Ada guru yang menyampaikan bahwa mereka tidak bisa dan tidak tahu dalam memanfaatkan lingkungan sekolah sebagai sumber belajar, dan perlu adanya petunjuk yang jelas atau dalam bentuk bimbingan dari kepala sekolah. Jadi, dapat dikatakan bahwa pemanfaatan lingkungan sebagai sumber belajar belum dimanfaatkan secara optimal karena faktor ketidak tahuan dan faktor dari siswanya.

Untuk mengatasi masalah tersebut, perlu adanya bimbingan yang dilaksanakan Kepala Sekolah agar guru dapat memahami pemanfaatan lingkungan sebagai sumber belajar. Oleh karena itu dipilihlah salah satu pendekatan yaitu In House Training (IHT) bagi guru untuk meningkatkan profesionalitas guru dalam memanfaatkan lingkungan sebagai sumber belajar. IHT adalah program yang diselenggarakan di lingkungan sendiri menggunakan peralatan dan materi yang relevan dengan permasalahan yang dihadapi, sebagai upaya untuk meningkatkan kompetensi yang dibutuhkan (Ayuningtyas et al., 2017; Jayadiputra, 2018; Sunita, 2019; dan Subekti, 2019. Jadi berdasarkan jabaran tersebut dapat dikatakan bahwa IHT adalah sebuah program pelatihan yang dilakukan di lingkunganya sendiri menggunakan peralatan dan materi yang relevan untuk menyelesaikan masalah yang ada. Dengan adanya IHT masalah-masalah yang dihadapi oleh guru akan dipecahkan bersama dan akan diberikan pelatihan yang nantinya berdampak terhadap peningkatan profesionalisme guru. Hal ini didukung oleh hasil penelitian yang dilakukan sebelumnya.

Penelitian yang dilakukan Rusdin (2017) menyatakan bahwa Pengembangan kompetensi guru yang telah dilakukan melalui pendidikan dan pelatihan di SMP Negeri 02 Ligang Bigung Kutai Barat secara akumulatif mampu menambah keterampilan dan keahlian guru sesuai bidang tugasnya. Sunita, (2019) peningkatan kemampuan guru dalam menyusun Program Pembelajaran pada mata pelajaran Normatif dan Adaptif, setelah dilakukan In 
House Training di Sekolah secara terprogram. Berdasarkan data yang diperoleh dalam Penelitian Tindakan Sekolah (PTS) ini maka dapat disimpulkan bahwa penerapan In House Training dapat meningkatkan kemampuan guru Normatif dan Adaptif dalam menyusun Program Pembelajaran di SMK Negeri 1 mas Ubud tahun pelajaran 2016/2017. Jayadiputra (2018) menyatakan bahwa terdapat peningkatan kompetensi guru setelah di berikan IHT.

Berkaitan dengan hal tersebut atas maka dalam penelitian tindakan sekolah ini dirumuskan sebuah tujuan yaitu untuk mengetahui peningkatan Profesionalitas Guru Dalam Pemanfaatan Lingkungan Sekolah Sebagai Sumber Belajar Melalui In House Training di SMA Negeri 2 Leuwidamar Tahun Pelajaran 2018/2019. Dengan adanya IHT ini masalah tentang pemanfaatan lingkungan belajar sebagai sumber belajar bisa diatasi.

\section{Materials and Methods}

Penelitian ini adalah Penelitian Tindakan Sekolah (PTS) sehingga dalam pelaksanaannya menekankan pada peningkatan profesionalitas guru dalam memanfaatkan lingkungan sebagai sumber belajar. Metode yang digunakan dalam penelitian ini adalah deskriptif analitis melalui PTS, yaitu suatu studi untuk mengumpulkan data, mendeskripsikan, mengolah, menganalisa, menafsirkan dan menyimpulkan data sehingga diperoleh gambaran yang sistematis. Pengambilan data Penelitian Tindakan Sekolah ini (PTS) dilaksanakan terhadap profesionalitas guru dalam memanfaatkan lingkungan sebagai sumber belajar di SMA Negeri 2 Leuwidamar.

Subjek Penelitian ini adalah guru mata pelajaran Bahasa Indonesia dua orang, guru IPA tiga orang, guru matematika dua orang, Guru PAI satu orang dan guru Bahasa Inggris dua orang, yang berjumlah 10 orang. Dari 10 orang guru tersebut dilihat perkembangannya setelah dilakukan tindakan yang dimulai dari siklus I, II.

Pengumpulan data dalam penelitian tindakan sekolah ini dilakukan dengan menggunakan perangkat instrumen yang terdiri dari: 1) Tes Uji Kompetensi (Instrumen pengujian) terhadap mata pelajaran yang diajarkan berdasarkan siklus yang telah ditentukan, 2) Angket siswa dan angket guru, 3) Lembar observasi, 4) Wawancara, dan 5) Refleksi. Analisis data yang digunakan pada penelitian ini adalah analisis data deskriptif kuantitatif. Target yang diharapkan pada penelitian ini adalah guru mampu membuat skenario pembelajaran dengan memanfaatkan lingkungan sekolah sebagai sumber belajar, Guru mampu melaksanakan pembelajaran dengan memanfaatkan lingkungan sekolah sebagai sumber belajar dan guru mampu berdiskusi secara aktif dan kreatif, dan mampu pemanfaatan menyelesaikan masalah yang dihadapinya secara efektif dan efisien dalam menentukan sumber belajar yang potensial terdapat pada lingkungan.

\section{Results and Discussion}

Pelaksanaan In House Trainining (IHT) di SMA Negeri 2 Leauwidamar, diharapkan mampu memecahkan masalah yang dijumpai pada prasiklus sehingga pada awal penelitian ini (pra siklus) dapat disajikan dan adanya gambaran yang jelas untuk mengatasinya pada siklus berikutnya. Diharapkan pula dengan IHT dapat memberikan tuntunan nyata bagi guru sehingga terjadi perbaikan dan peningkatan profesioinalitas guru dalam pemanfaatan lingkungan sekolah sebagai sumber belajar dapat meningkat di SMA negeri 2 Leauwidamar.

Berdasarkan hasil yang dicapai dalam penilaian pada siklus I guru yang memanfaatkan lingkungan sekolah sebagai sumber belajar dengan katagori A (Amat Baik) adalah sebanyak dua orang atau 20\% dimana telah terjadi peningkatan pemahaman guru sehingga mencapai peningkatan dari Prasiklus. Guru yang telah memperoleh kategori A (Amat Baik) adalah guru yang telah mampu menentukan jenis lingkungan sekolah sebagai sumber belajar secara tepat. Sedangkan guru yang memperoleh kategori B (Baik), sebanyak $80 \%$ dan hal ini masih memerlukan bimbingan lebih lanjut dari Kepala Sekolah bersama 
fasilitator yang mendampinginya agar dapat meningkatkan kemampuannya yang lebih baik pada siklus berikutnya.

Dari refleksi terhadap seluruh kegiatan pada siklus I, maka ditemukan beberapa hambatan yang mengakibatkan belum optimalnya profesionalitas guru pemanfaatan lingkungan sekolah sebagai sumber belajar. Adapun hambatan-hambatan tersebut, antara lain masih ada beberapa guru yang belum sepenuhnya memahami manfaat lingkungan sekolah sebagai sumber belajar, dan guru dalam memilih sumber belajar serta memilih strategi pembelajaran dengan pemanfaatan lingkungan sekolah belum sesuai dengan yang diharapkan. Hal ini terlihat dalam skenario pembelajaran guru pada: aspek 1. jenis sumber belajar dari lingkungan sekolah tidak tercantum, padahal materi pelajaran ada kaitannya dengan lingkungan sekolah; aspek 2. Kesesuaian antara materi pelajaran dengan media dan strategi pembelajaran masih kurang; aspek 4. Kesesuaian antara tujuan pembelajaran dengan sumber bahan, lebih banyak hanya mencantumkan buku paket sebagai satu-satunya sumber belajar. Namun demikian nilai terendah yang dicapai guru adalah B.

Pelaksanaan In House Training pada siklus II lebih di fokuskan pada praktik guru dalam menyusun program pembelajaran dengan memasukkan unsur lingkungan sekolah sebagai sumber belajar. Dalam pelaksanaannya Peneliti ingin mengetahui peningkatan terhadap profesionalitas guru dalam memanfaatkan lingkungan sekolah sebagai sumber belajar. Selanjutnya dilakukan diskusi tentang hambatan- hambatan yang dialami dalam menyusun skenario pembelajaran dan pelaksanaan pembelajaran di kelas pada siklus II melalui kegiatan In House Training (IHT) dan sangat difokuskan kepada guru yang pemahamannya masih belum optimal.

Hasil Siklus II adalah: 1) Sebanyak 10 orang guru yang mendapat nilai A (Amat Baik), 2) Sebanyak 10 orang guru yang telah memanfaatkan lingkungan sekolah sebagai sumber belajar, dan 3) Total skor maksimal dengan rata-rata 93, sehingga masuk kategori A (Amat Baik). Berdasarkan persentase guru yang memanfaatkan lingkungan sebagai sumber belajar adalah sebanyak 100\%, terjadi kenaikan dari Siklus I dan guru dapat memahami pemanfaatan lingkungan sekolah sebagai sumber belajar setelah mendapatkan bimbingan secara intensif melalui kegiatan IHT di SMA Negeri 2 Leauwidamar.

Dengan data siklus II tersebut diatas semua guru yang mengikuti Program in House Training (IHT) telah memahami dengan baik tentang pemanfaatan lingkungan sebagai sumber belajar. Hal ini terbukti bahwa pada siklus II sebanyak 10 orang guru yang mencapai nilai A (Amat merupakan suatu bukti bahwa pelaksanaan In House Training terbukti dapat meningkatkan profesionalitas guru dalam pemanfaatan lingkungan sekolah sebagai sumber belajar

Dengan demikian pelaksanaan In House Training yang dilaksanakan di SMA Negeri 2 Leauwidamar dapat meningkatkan profesionalitas guru dalam memanfaatkan lingkungan sebagai sumber belajar secara optimal dan guru yang menjadi subjek dalam Penelitian ini merasa memfasilitasi dalam memanfaatkan lingkungan sekolah sebagai sumber belajar. Hal ini karena dengan adanya bimbingan dari kepala sekolah akan membuat guru lebih merasa termotivasi untuk mengembangkan kemampuannya karena proses bimbingan yang dilakukan bukanlah sebuah proses perintah. Brown dan Trusty (2005:28) dalam Erwin Erlangga, Sugiyo, (2015); Gumilar \& Munzir, (2018) bahwa peranan pemimpin dalam hal ini kepala sekolah mempengaruhi dan mengarahkan serta memotivasi semua personel sekolah untuk mencapai tujuan Pendidikan.

Hasil penelitian ini sejalan dengan hasil penelitian yang dilakukan oleh (Dharmawan et al., 2016) dengan judul Model Pembinaan 'In-House Training' Sebagai Upaya Untuk Meningkatkan Kemampuan Guru Dalam Penelitian Dan Penulisan Karya Ilmiah. Hasil dari pembinaan ini menunjukkan adanya peningkatan yang cukup signifikan, sekitar $30 \%$ pada kemampuan guru dalam melakukan Penelitian Tindakan Kelas (PTK). Selanjutnya hasil 
penelitian yang dilakukan oleh Jayadipura (2018) dengan judul In House Training untuk Meningkatkan Kemampuan Guru dalam Menyusun RPP. Berdasarkan penelitian yang telah dilakukan dapat disimpulkan bahwa kegiatan In House Training (IHT) dapat meningkatkan kompetensi guru SMP Negeri 2 Tempuran dalam menyusun Rencana Pelaksanaan Pembelajaran (RPP). Ini terlihat dari hasil yang diperoleh dimana pada siklus I, dari 6 guru yang di observasi 3 diantaranya masih berada pada kategori cukup yaitu guru 3, guru 4 dan guru 6. Selanjutnya pada siklus ke II terlihat guru 3, guru 4 dan guru 6 sudah berada pada kategori sangat baik.

\section{Conclusion}

Berdasarkan penelitian yang telah dilakukan dapat disimpulkan bahwa pelaksanaan Penelitian Tindakan Sekolah yang dilaksanakan di SMA Negeri 2 Leauwidamar telah terbukti keberhasilannya, dan mampu meningkatkan profesionalitas guru dalam memanfaatkan lingkungan sekolah sebagai sumber belajar di SMA Negeri 2 Leauwidamar.

\section{References}

Ayuningtyas, A. E., Slameto, S., \& Dwikurnaningsih, Y. (2017). Evaluasi Program Pelatihan In House Training (IHT) di Sekolah Dasar Swasta. Kelola: Jurnal Manajemen Pendidikan, 4(2), 171. https://doi.org/10.24246/j.jk.2017.v4.i2.p171-183.

Dharmawan, K., Ramona, Y., \& Rupiasi, N. (2016). Model Pembinaan in-House Trainingâ Sebagai Upaya Untuk Meningkatkan Kemampuan Guru Dalam Penelitian Dan Penulisan Karya Ilmiah. Jurnal Udayana Mengabdi, 15(2), 74-81.

Erwin Erlangga , Sugiyo, S. P. (2015). Kepemimpinan Kepala Sekolah, Kompetensi Profesional Berpengaruh Terhadap Kinerja Guru Bkmelalui Motivasi Kerja. Jurnal $\begin{array}{llll}\text { Bimbingan } \quad \text { Konseling } \quad \text { (Semarang), } & \text { 72-78. }\end{array}$ https://doi.org/10.15294/jubk.v4i2.9847.

Gumilar, G. G., \& Munzir, T. (2018). Pengaruh Gaya Kepemimpinan Kepala Sekolah Terhadap Kinerja Guru Sma Global Indo-Asia Batam. Jurnal Dimensi, 7(2), 232-238. https://doi.org/10.33373/dms.v7i2.1710.

Jayadiputra, Y. (2018). In House Training untuk Meningkatkan Kemampuan Guru dalam Menyusun RPP. JURNAL IDAARAH, II(2), 260-268.

Rochanah. (2018). Lingkungan Alam Sebagai Media Kekuasaan Allah Pada Anak Usia. Vol 6/No.hana@stainkudus.ac.id

Rohayati, H. (2018). Pemanfaatan Lingkungan Sekitar sebagai Media Pendukung Pembelajaran IPA untuk Meningkatkan Hasil Belajar Peserta Didik di SDN 263 Rancaloa. Jurnal Elementaria Edukaia, 1(1), 94-100.

Rusdin. (2017). Pendidikan dan Pelatihan Sebagai Sarana Peningkatan Kompetensi Guru di SMP Negeri 2 Linggang Bigung. Jurnal Administrative Reform, 5(4), 200-212.

Subekti, B. D. (2019). Upaya Peningkatan Kompetensi Guru Dalam Pembuatan Skenario Pembelajaran Inovatif Melalui Iht (in House Training) Di Sd Negeri 1 Wirotaman. Inventa, 3(1), 80-86. https://doi.org/10.36456/inventa.3.1.a1809.

Sunita, I. W. (2019). Peningkatan Kemampuan Guru Normatif dan Adaptif dalam Menyusun Program Pembelajaran melalui Pelaksanaan In House Training. Jurnal Pedagogi Dan Pembelajaran, 2(1), 16. https://doi.org/10.23887/jp2.v2i1.17603. 